Article

\title{
Investigating Various Permutations of Copper Iodide/FeCu Tandem Materials as Electrodes for Dye-Sensitized Solar Cells with a Natural Dye
}

\author{
Abdul Hai Alami ${ }^{1,2}, * \mathbb{D}$, Mohammed Faraj ${ }^{2}$, Kamilia Aokal ${ }^{2}$, Abdullah Abu Hawili $^{3}$, \\ Muhammad Tawalbeh ${ }^{1}$ (D) and Di Zhang ${ }^{1,2}$ (D) \\ 1 Sustainable and Renewable Energy Engineering Department, University of Sharjah, Sharjah 27272, UAE; \\ mtawalbeh@sharjah.ac.ae (M.T.); zdi@sharjah.ac.ae (D.Z.) \\ 2 Center for Advanced Materials Research, Research Institute of Science and Engineering, \\ University of Sharjah, Sharjah 27272, UAE; mfaraj@sharjah.ac.ae (M.F.); k_aokal@outlook.com (K.A.) \\ 3 Sharjah Research Academy, Sharjah 27272,UAE; a.abouhewelle@sra.ae \\ * Correspondence: aalalami@sharjah.ac.ae; Tel.: +971-56-160-5355
}

Received: 3 April 2020; Accepted: 17 April 2020; Published: 19 April 2020

\begin{abstract}
This work presents the synthesis and deposition of $\mathrm{CuI}$ and $\mathrm{FeCu}$ materials on copper substrates for dye-sensitized solar cell applications. $\mathrm{FeCu}$ is a metastable alloy of iron and copper powders and possesses good optical and intrinsic magnetic properties. Coupled with copper iodide as tandem layers, the deposition of these two materials was permutated over a pure copper substrate, characterized and then tested within a solar cell. The cell was sensitized with a natural dye extracted from a local desert plant (Calotropis gigantea) and operated with an iodine/triiodide electrolyte. The results show that the best layer arrangement was $\mathrm{Cu} / \mathrm{FeCu} / \mathrm{CuI}$, which gave an efficiency of around $0.763 \%$ (compared to $0.196 \%$ from reported cells in the literature using a natural sensitizer).
\end{abstract}

Keywords: copper iodine; FeCu alloys; ball milling; dye-sensitized solar cells; natural sensitizers; Calotropis gigantea

\section{Introduction}

Dye Sensitized Solar Cells (DSSC) are the most investigated third-generation solar cell technologies due to their low cost, ease of fabrication, and relatively high efficiencies (about 10\%) [1,2]. They were introduced by $\mathrm{O}^{\prime}$ Regan and Gratzel who employed nanocrystalline mesoporous $\mathrm{TiO}_{2}$ films and reported a very high conversion efficiency of around $7.1-7.9 \%$ and $12 \%$ in simulated solar light and diffuse daylight, respectively [3].

Extensive research has been conducted to enhance the performance of DSSC by modifying the physicochemical properties of the main components of the cells. Most of this research focused on exploring new dyes, increasing the surface area of the mesoporous layer and improving the working electrode materials and configurations [4]. Lim et al. reported that enhancing DSSC by the use of an ethylene glycol-based polymer gel electrolyte with $\mathrm{ZrO}_{2}$ nanofillers resulted in a 5.6\% power conversion efficiency [5]. Iglesias et al. showed, in their study, that the use of carbon nanohorns and their resultant dye conjugates led to an increase in the DSSC efficiency from $4.07 \%$ to $6.24 \%$ [6]. Another study on the modification of the DSSC by Li et al. showed the use of $\mathrm{ZnO}$ hollow microspheres coated by $\mathrm{TiO}_{2}$ in Quantum Dots DSSC to enhance the light harvesting efficiency of the cell, resulting in a power conversion efficiency of $3.16 \%$ compared to $1.54 \%$ in the absence of the $\mathrm{TiO}_{2}$ coating [7]. Moreover, in their attempt at commercializing DSSC, Cheng et al. reported the development of a quasi-solid DSSC with a long-term stability with a conversion efficiency of $8.63 \%$ [8]. In addition, due to intensive research, the efficiency of the DSSC reached a record value of $14.30 \%$ in 2015 [9]. Moreover, 
metal oxides are among the materials that are commonly investigated for their role in enhancing the efficiencies of DSSCs [10,11]. They are used for enhancing the mesoporous layers [12], bandgap engineering [13] and in counter electrodes enhancements [14]. For example, Sharma et al. reported that using $\mathrm{ZnO}$ nanolayers in DSSCs resulted in an efficiency of $0.49 \%$ [15].

Today, more research is directed toward examining new materials as counter electrodes [16]. Platinum (Pt), despite its high cost, is the most commonly used material as counter electrodes. Several lower-cost materials were considered in the literature to substitute $\mathrm{Pt}$, such as tungsten, selenide, nickel, aluminum, ruthenium, copper, zinc, conducting polymers and carbonaceous materials $[17,18]$. For example, Vijaya et al. reported that $\mathrm{MoS}_{2}$ nanosheets-based counter electrodes coupled with reduced graphene oxide for DSSC exhibited a fill factor of 0.42 , a power conversion efficiency of $8.1 \%$ compared with 0.47 fill factor, and a power conversion efficiency of $6.8 \%$ obtained by using Pt-counter electrodes [19]. Another attempt at making Pt-free counter electrodes by Huang et al. showed a power conversion efficiency of $9.21 \%$ utilizing a nano yolk-shell structure of nitrogen-doped $\operatorname{CoS}_{2}$ [20]. A study by Kim et al. reported that integrating Tellurium-doped mesoporous carbon nanomaterials as a transparent counter electrode for bifacial DSSC resulted in $9.43 \%$ and $8.06 \%$ power conversion efficiencies under front and rear-side irradiation, respectively [21]. Moreover, Nan et al. showed an economic replacement of $\mathrm{Pt}$ counter electrodes using $\mathrm{NiCo}_{2} \mathrm{~S}_{4} /$ reduced graphene oxide with a $6.01 \%$ efficiency [22].

Copper, in particular, has several properties that deem it as a favorable candidate for various electrical and thermal applications. These include its high thermal conductivity, ease of fabrication, availability, relatively low cost, durability, high electrical conductivity and resistance for corrosion [14]. Copper is typically combined with other materials to better serve certain applications. For instance, cupric oxide $(\mathrm{CuO})$ and cuprous oxide $\left(\mathrm{Cu}_{2} \mathrm{O}\right)$ have band gaps of $1.21-2.1 \mathrm{eV}$ and $2.2-2.9 \mathrm{eV}$, respectively, which made them very attractive as visible light absorption materials [23,24]. Zhuang et al.'s study highlighted that electron transport could be enhanced by introducing copper into the $\mathrm{ZnO}$ layer in photoelectrodes resulting in a 1.6 times enhancement of the power conversion efficiency [25]. DSSC with Pt-free counter electrodes of $\mathrm{Cu}_{2} \mathrm{ZnSnS}_{\mathrm{x}} \mathrm{Se}_{4-\mathrm{x}}$ nanosheets on FTO substrate was reported on by Mohammadnezhad et al. to have a $5.73 \%$ power conversion efficiency compared to $5.78 \%$ using the Pt-based CE [26]. Moreover, cuprous iodide (CuI) is also used as a hole transporter in DSSC [27]. $\mathrm{CuI}$ has very high hole mobility and transparency, it is chemically stable, easy to deposit, and has a low production cost $[28,29]$. It is worth mentioning that the most commonly employed electrolyte is iodide/triiodide [30,31].

The Fe-Cu bimetallic alloy has been integrated into several applications due to its notable mechanical electrical and optical properties [32,33]. It was integrated in a previous work by Alami et al. as a mesoporous layer replacing the $\mathrm{TiO}_{2}$ layer in DSSC to a good degree of success [34].

The photosensitizers in DSSC are classified principally as three main types; (i) metallic complexes—specifically ruthenium(II)—(ii) zinc porphyrin derivatives, and (iii) organic dyes [2,35]. In the literature, several natural dyes were utilized to prepare DSSC, such as spinach, rosella, red beet roots, red cabbage, red turnip, rhoeo spathacea stream, curcumin, red perilla, sesbania grandiflora scarlet, achiote seed, blue pea, and pomegranate [36]. The dye extracted from Calotropis is a natural dye; hence, it is expected to contain a combination of pigments. This combination is anticipated to extend the absorption range beyond that of a single pigment, which is believed to improve the DSSC efficiency [37].

In this work, the synthesis and deposition of tandem layers of $\mathrm{FeCu}$ and $\mathrm{CuI}$ on a copper substrate was investigated for dye-sensitized solar cells application. The available permutations of materials arrangement were executed (i.e., $\mathrm{Cu} / \mathrm{CuI}, \mathrm{Cu} / \mathrm{FeCu} / \mathrm{CuI}$ and $\mathrm{Cu} / \mathrm{CuI} / \mathrm{FeCu}$ ), and their effect on the solar cell performance (mainly the efficiency) is reported. The cells were sensitized via a natural dye and thus, the cells were also compared to the performance of their counterparts reported in the reviewed literature. The pertinent microstructural and optical characterizations are also reported. 


\section{Materials and Methods}

The following paragraphs detail the synthesis and deposition of the materials on the copper substrates. The solar cell construction and testing are also specified. High-quality copper sheets $0.2 \mathrm{~mm}$ in thickness and measuring $1 \times 10 \mathrm{~cm}$ were used as substrates for the deposition of $\mathrm{CuI}$ and $\mathrm{FeCu}$ thin films. The sheets were initially sonicated in a solution containing a 1:1 volume ratio of ethanol to acetone for one hour at $55-60{ }^{\circ} \mathrm{C}$ to remove any organic contaminants.

\subsection{Synthesis of the FeCu Material}

Binary metastable Fe-Cu powder was synthesized via dry-ball milling with a 1:1 mass ratio of pure iron and copper powders (used as received from Sigma-Aldrich). The mechanical alloying took place in the Fritsch (FRITSCH GmbH Idar-Oberstein, Germany) premium line Pulverisette 7 planetary ball mill at a $600 \mathrm{rpm}$ milling speed for ten hours milling time. The ball to powder ratio was fixed at 6:1.

The ball mill machine was also used in order to apply a uniform layer of coating on the used electrodes by virtue of the kinetic energy and the centrifugal motion of the milling and without using balls. For this part of the experiment, three grams of previously prepared FeCu powder was placed in a crucible along with the thin copper substrate fixed on the walls (as a collar). The milling speed was fixed at $600 \mathrm{rpm}$, maintained for two consecutive hours until a layer of FeCu was obtained on the $\mathrm{Cu} / \mathrm{CuI}$ collar, as depicted in Figure 1a.

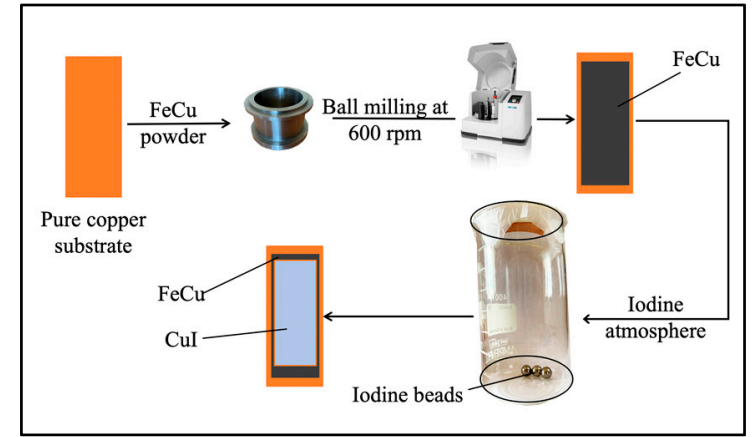

(a)

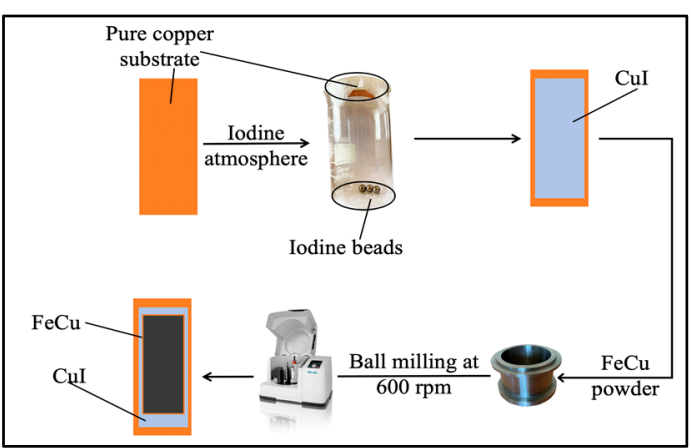

(b)

Figure 1. (a) FeCu deposition on pure $\mathrm{Cu}$ substrate followed by $\mathrm{CuI}$ growth on the resulting $\mathrm{Cu} / \mathrm{FeCu}$ collar and (b) CuI growth on $\mathrm{Cu}$ substrate followed by ball-less milling of a $\mathrm{Cu} / \mathrm{CuI}$ collar to deposit $\mathrm{FeCu}$ on CuI.

\subsection{Synthesis of Copper Iodide (CuI)}

The $\mathrm{Cu}$ sheets were dried by $\mathrm{N}_{2}$ gas and transferred into the route of $\mathrm{CuI}$ deposition. This involved the growth of an intrinsic layer of $\mathrm{CuI}$ on the surface of the copper sheets and took place in a beaker sealed with parafilm that contained $6 \mathrm{mmol}$ pure Iodine beads. The beads decompose at room temperature, generating corrosive $\mathrm{I}_{2}$ fumes that reduce copper (II) ions to form copper (I) iodide on the surface of the substrate and thus, generate an adherent gray-colored CuI film. Figure $1 \mathrm{~b}$ shows the process of growing the $\mathrm{CuI}$ film and the subsequent milling of FeCu powder to add the FeCu on top of CuI.

Following a two-step process, iodide is oxidized by $\mathrm{Cu}^{2+}$ ions to form intermediate $\mathrm{CuI}_{2}$.

$$
\mathrm{Cu}^{2+}+2 \mathrm{I}^{-} \rightarrow \mathrm{Cu}^{+}+\mathrm{I}_{2}
$$

$\mathrm{CuI}_{2}$ is unstable due to the strong reducing properties of iodide, which reduces $\mathrm{Cu}^{2+}$ to $\mathrm{Cu}^{+}$.

$$
\mathrm{CuI}_{2} \rightarrow \mathrm{CuI}+\frac{1}{2} \mathrm{I}_{2}
$$


$\mathrm{CuI}$ has three known solid phases. At room temperature and below $369^{\circ} \mathrm{C}$, it arranges with a face-centered cubic (FCC) crystal structure (known as $\gamma$-CuI). Between $369^{\circ} \mathrm{C}$ and $407^{\circ} \mathrm{C}$, it forms a hexagonal close-packed $(\mathrm{HCP})$ structure $(\beta-\mathrm{CuI})$. Above $407^{\circ} \mathrm{C}$, it forms a disordered face-centered cubic (FCC) structure $(\alpha-\mathrm{CuI})$.

Having four lone pairs, iodine potentially coordinates to four surrounding atoms. For an enhanced catalytic response, however, reducing the coordination number to two copper atoms allows the interaction between copper centers and externally supplied ligands and sensitizers. Since the coordination of copper (I) to four ligands is energetically favorable, this augments the chances of dye molecules intercalation and potential interaction with incident solar radiation. Moreover, according to Yang et al., $\mathrm{CuI}$ behaves more like a p-type semiconductor, contrarily to $\mathrm{TiO}_{2}$ [38].

\subsection{Microstructural Characterization of Material}

The microstructure of the produced electrodes was examined by scanning electron microscopy (SEM), both regularly, using a VEGA3 TESCAN (Tescan Analytics, Actipôle St Charles, Fuveau, France) electron microscope operating at $30 \mathrm{kV}$ acceleration voltage used to investigate the topography of the produced material, and with an Apreo C field emission (FE-SEM) from Thermoscientific (Thermo Fisher Scientific, Brno, Czech Republic) operating at low vacuum and $15 \mathrm{kV}$ with an electrostatic lens. The TESCAN SEM has a coupled provision for energy dispersive $x$-ray spectroscopy (EDS) and was also used to take cross-sectional SEM images of the electrodes. X-ray diffraction (XRD) measurements were also taken for the electrodes on a Bruker (Bruker GmbH, Wien Austria) D8 Advance Da Vinci multipurpose $X$-ray diffractometer, with $\mathrm{Cu} \mathrm{K} \alpha$ radiation operating at $\lambda=1.5406 \AA$. Raman spectroscopy was performed at room temperature in backscattering configuration with a Renishaw inVia Raman microscope (Renishaw, gloucestershire UK) via its visible $514 \mathrm{~nm}$ laser at a resolution of $1 \mathrm{~cm}^{-1}$.

Spectral absorbance in the Vis-NIR range $(375-815 \mathrm{~nm})$ of the films was carried out via a Maya 2000-Pro high-resolution spectrometer (Ocean Optics Inc.,Photonic Solutions, Edinburgh, UK) with a $10-\mu \mathrm{m}$ entrance slit. The spectrometer has a resolution of $0.2 \mathrm{~nm}$ and 300 lines per $\mathrm{mm}$ diffraction gratings. The signals are transported via a fiber optic cable that is 2-m long, with a 200- $\mu \mathrm{m}$-core diameter. The integrating sphere (OceanOptics ISP-REF, with a sample aperture of $1.016 \mathrm{~cm}$ ) has a built-in tungsten halogen light source (Ocean Optics LS-1-LL) and was used to measure the films under the effects of reflectance. A reference surface of a pure copper substrate was used to store baseline reflectance $(100 \%)$ spectra to facilitate comparison between the various samples.

\subsection{Dye Extraction and Characterization}

The natural sensitizer for this project was extracted from the Calotropis gigantea plant that grows naturally in the United Arab Emirates. Calotropis gigantea leaves were washed thoroughly with water and liquid soap to remove any surface impurities and were left to dry in air. The leaves were then cut up into smaller pieces with an average surface area equal to $0.25 \mathrm{~cm}^{2}$, avoiding the midrib and branched out veins. The leaves were then sonicated for an hour in a mixture containing a 3:1 mass ratio of the leaves to ethanol and were subsequently filtered through a PTFE syringe filter of $0.45 \mu \mathrm{m}$ pores for electrode adsorption.

The dye characterization included a Fourier Transform Infrared Spectrum (FTIR) analysis done using ATR-FTIR spectra, recorded on a Burker Platinum ATR Tensor II FT-IR (Bruker GmbH, Wien Austria) spectrophotometer within the wave band of $4000 \sim 500 \mathrm{~cm}^{-1}$.

\subsection{Solar Cell Assembly}

To study the effect of this tandem deposition on the performance of the solar cell device that is intended for this study, four electrode permutations were produced, as seen in Figure 2. The variation of the spectral and microstructural properties of these layers was examined to arrive at the most desirable properties for the best device performance. 


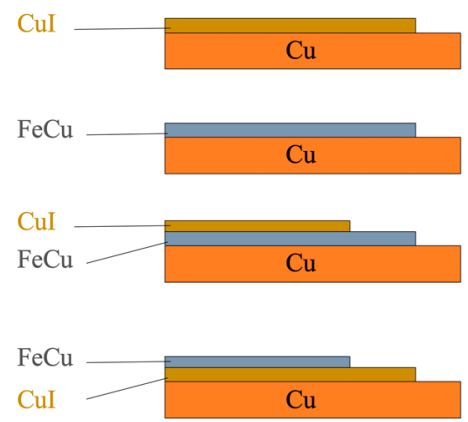

Figure 2. Deposition order of the $\mathrm{FeCu}$ and $\mathrm{CuI}$ materials on pure copper substrate (top to bottom: $\mathrm{Cu} / \mathrm{CuI}, \mathrm{Cu} / \mathrm{FeCu}, \mathrm{Cu} / \mathrm{FeCu} / \mathrm{CuI}$ and $\mathrm{Cu} / \mathrm{CuI} / \mathrm{FeCu}$ ).

The construction and testing of the cells were arranged to follow an inverted stratification, where the negative electrode is one of the combinations (highlighted in Figure 2) with an added layer of titanium dioxide $\left(\mathrm{TiO}_{2}\right)$, and the positive terminal is the $\mathrm{Pt}$ photoanode.

A standard Ti-nanoxide T/SP paste from Solaronix (Solaronix, Aubonne, Switzerland) was drop-cast onto the aforementioned copper substrates occupying an active area of $\sim 0.25 \mathrm{~cm}^{2}$. The electrodes were heated up to $550^{\circ} \mathrm{C}$ until there was a noticeable color change, a process that took around $30 \mathrm{~min}$. The electrodes were then placed in the natural dye overnight for dye adsorption.

The positive electrode comprised of a ready-made $0.2 \mathrm{~cm}$ thick platinum $(\mathrm{Pt})$-coated (screen printed) Platisol T/SP precursor onto fluorine-doped tin oxide (FTO) glass measuring $2 \times 2 \mathrm{~cm}$ from solaronix. Iodolyte AN-50 was used as the electrolyte, also from Solaronix.

A sample of the assembled device is shown in Figure 3, featuring the $\mathrm{Cu} / \mathrm{FeCu} / \mathrm{CuI}$ electrode.

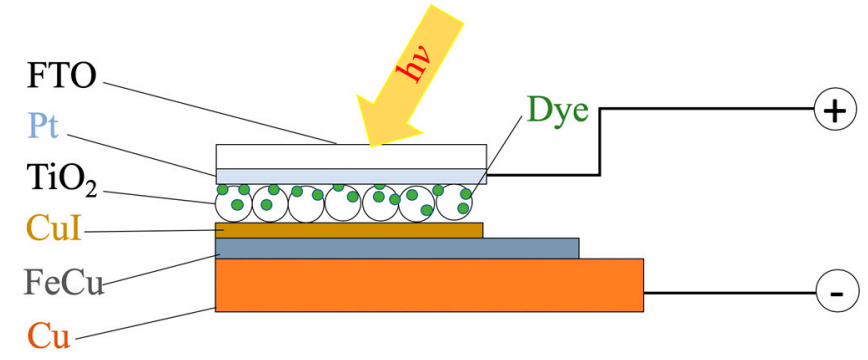

Figure 3. The assembled device (solar cell), featuring the $\mathrm{Cu} / \mathrm{FeCu} / \mathrm{CuI}$ electrode.

\subsection{Solar Cell Testing and Characterization}

The current density-voltage (J-V) measurements of the DSSC were carried out on a Keithley 2400 SourceMeter under an ABET SunLite solar simulator at AM1.5G and $1000 \mathrm{~W} \mathrm{~m}^{-2}$ irradiance at room temperature.

\section{Results}

The following paragraphs present the main results obtained from the deposition and characterization of the dye and electrodes materials, as well as the tests conducted to characterize the produced solar cells.

\subsection{Microstructural characterization}

\subsubsection{Scanning Electron Microscopy (SEM)}

The material deposition was first verified via SEM measurements. The $\mathrm{FeCu}$ and $\mathrm{CuI}$ deposition on the $\mathrm{Cu}$ substrate is shown in Figure 4a,b, respectively. The former depicts the homogenous $\mathrm{FeCu}$ coverage of the $\mathrm{Cu}$ substrate due to the high energy involved in depositing the $\mathrm{FeCu}$ powder on the 
$\mathrm{Cu}$ surface, while Figure $4 \mathrm{~b}$ shows the growth of $\mathrm{CuI}$ on the copper substrate, with a homogenous granular coverage of the substrate too. The EDS measurements shown in Figure 4c,d confirm the homogeneity, with $75.2 \%$ wt. copper and $24.8 \%$ wt. I for the $\mathrm{CuI}$, while $70 \%$ wt. $\mathrm{Cu}$ and $30 \% \mathrm{wt}$. Fe (due to interference from the copper substrate) is evident from the FeCu deposition EDS.

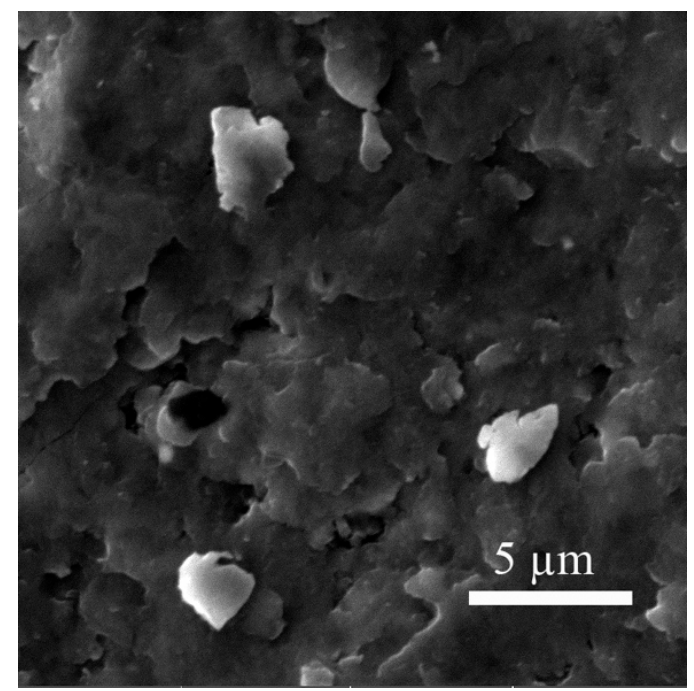

(a)
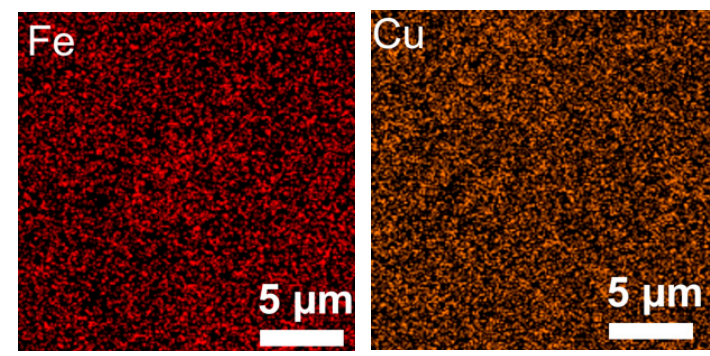

(c)

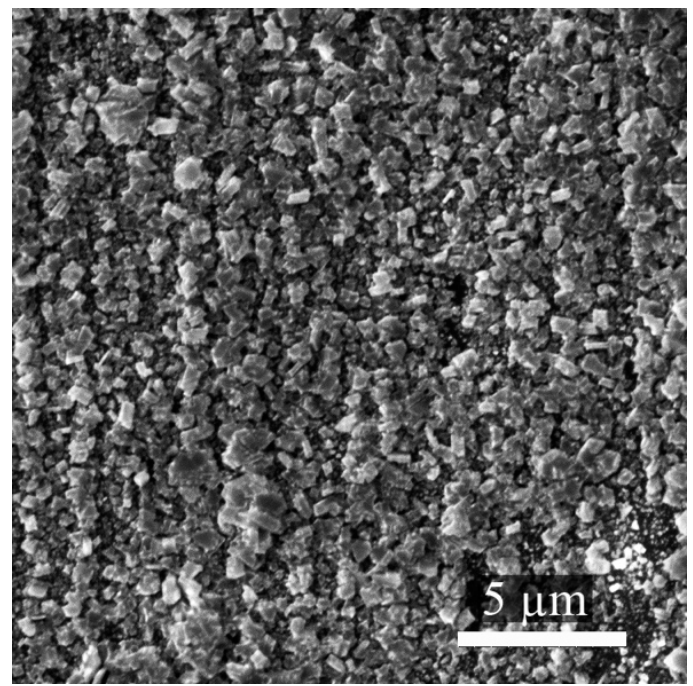

(b)
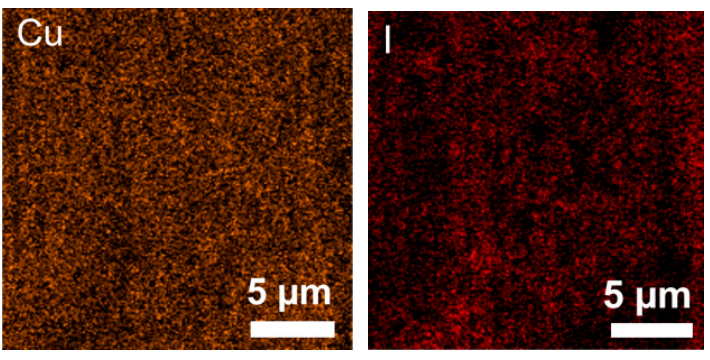

(d)

Figure 4. (a) FeCu deposition on the copper substrate, (b) CuI growth on $\mathrm{Cu}$, (c) EDS mapping of the FeCu distribution and (d) EDS mapping of the CuI distribution.

Field emission SEM (FE-SEM) was also used to highlight the deposition permutation of (i) $\mathrm{FeCu} / \mathrm{CuI}$ and (ii) $\mathrm{CuI} / \mathrm{FeCu}$ on the copper substrate, as shown in Figure 5a,b, respectively. It is also used to further examine the homogeneity of copper iodine formation on the copper substrate, as seen in Figure 5c.

The unimpeded CuI growth over the copper substrate is seen to commence growth as monolithic columns, then break down into triangular grains (see the contrast between Figure $4 \mathrm{~b}$ and Figure $5 \mathrm{c}$ ). On the other hand, the intrinsic high-energy nature of $\mathrm{FeCu}$ deposition shows surfaces that are more homogenous and exhibit a suppressed microstructure, mainly due to the physical erosion that accompanies the centrifugation that takes place in the milling apparatus.

The effect of the microstructure on the performance of the produced devices was further investigated spectrally, as the physical properties affect the direct bandgap of the materials, and hence, the interaction with incident electromagnetic waves during solar cell testing. The tandem material deposition (e.g., $\mathrm{FeCu} / \mathrm{CuI}$ on copper) is stable and compact, again due to the energy in the milling machine that produces the adherent powder. The thickness of the material was measured using a cross-sectional SEM measurement shown in Figure 5d, where the layer has a thickness of 3.76-4.40 $\mu \mathrm{m}$. 


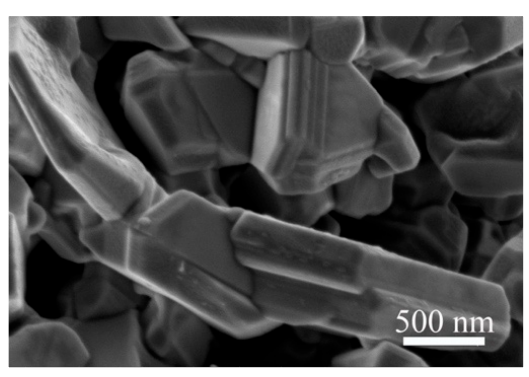

(a)

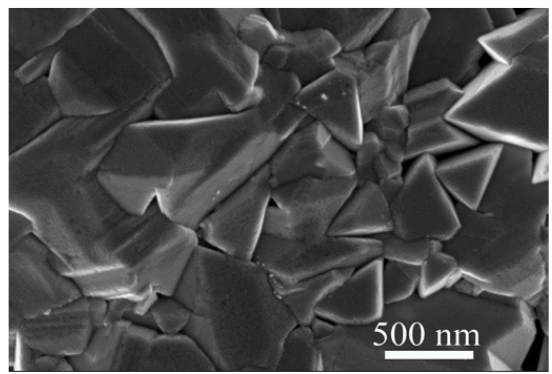

(c)

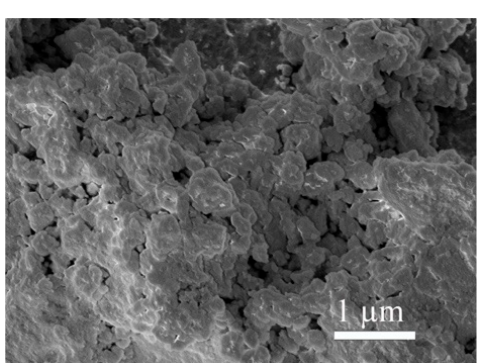

(b)

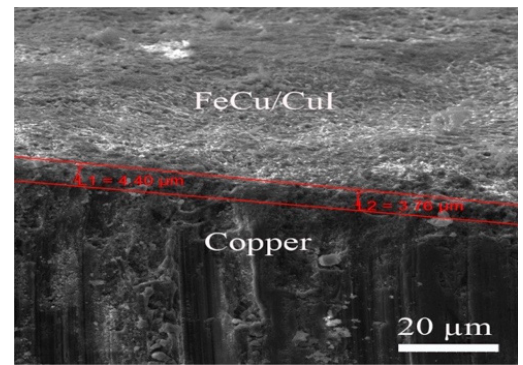

(d)

Figure 5. (a) Field emission scanning electron microscopy (FE-SEM) micrographs of (a) copper iodine growth over FeCu deposited on copper substrate, (b) FeCu ball-milled over CuI deposited on the cipper substrate, (c) CuI growth on copper substrate, showing monolithic CuI growth and (d) cross sectional $\mathrm{SEM}$ of $\mathrm{FeCu} / \mathrm{CuI}$ on copper substrate.

\subsubsection{Raman Spectroscopy and X-ray Diffraction}

Raman spectroscopy was performed on all produced electrodes with $\mathrm{CuI}$ films and the spectra are shown in Figure 6a. The optical transverse mode of $\mathrm{CuI}$ bonding vibration is visible at a peak of $120 \mathrm{~cm}^{-1}$ [39], after which the curves show similar trends as that of $\mathrm{FeCu}$ thin film as the top layer. Specimens with $\mathrm{FeCu}$ as the top layer do not show that particular peak, with all single points taken exhibiting the same behavior due to the strong scattering effect of the $\mathrm{FeCu}$ layer which has the ability to reduce the penetration depth of the $514 \mathrm{~nm}$ laser. Therefore, the existence of $\mathrm{CuI}$ on this electrode is more clearly depicted in the XRD spectra of Figure $6 \mathrm{~b}$ with an added $\mathrm{TiO}_{2}$ layer.

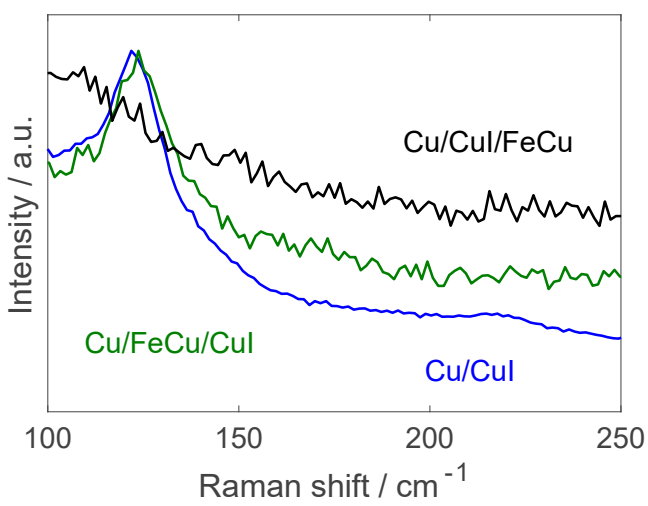

(a)

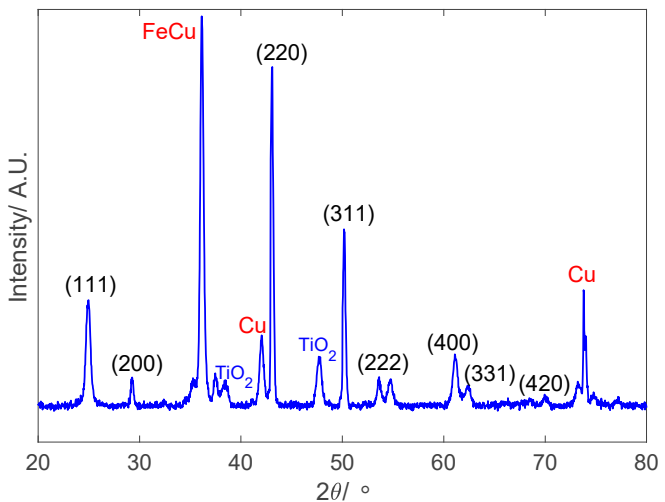

(b)

Figure 6. (a) Raman spectroscopy for all electrode deposition permutations and (b) X-ray diffraction patterns featuring the $\mathrm{Cu} / \mathrm{CuI} / \mathrm{Cu}$ electrode (crystallographic planes are shown for $\mathrm{CuI}$ ). 
The XRD patterns of the $\mathrm{Cu} / \mathrm{CuI} / \mathrm{FeCu}$ electrode shown Figure $6 \mathrm{~b}$ indicate the existence of all the expected compounds. The measured electrodes, in this case, with the added $\mathrm{TiO}_{2}$ layer, show strong signatures of $\mathrm{FeCu}, \mathrm{Cu}, \mathrm{CuI}$ as well as $\mathrm{TiO}_{2}$, where the $\mathrm{CuI}$ peaks are indicated with their corresponding crystallographic plane number. The XRD patterns are identical for all permutations of the electrodes produced, and hence, Figure $6 \mathrm{~b}$ is representative of all cases, as the penetration of the $\mathrm{X}$-rays covers the thin tandem materials and into the copper substrate.

\subsection{Spectral Absorptivity of Electrodes and FTIR Analysis of the Natural Dye Sensitizer}

The absorbance of all produced electrodes is shown in Figure 7a. Two broad peaks are observed for $\mathrm{FeCu}$-coated copper, one at $475 \mathrm{~nm}$ and another at $600 \mathrm{~nm}$. The latter could be attributed to the formation of charge transfer bands, owing to $\mathrm{FeCu}$ accepting electrons from the substrate. There seems to be a red shift in those very peaks as the effect is more pronounced in the $\mathrm{Cu} / \mathrm{FeCu} / \mathrm{CuI}$ structure. It can also be noticed that $\mathrm{CuI}$ absorbance peaks occur at shorter wavelengths preceding $410 \mathrm{~nm}$ while the absorbance decreases with the wavelength [40].

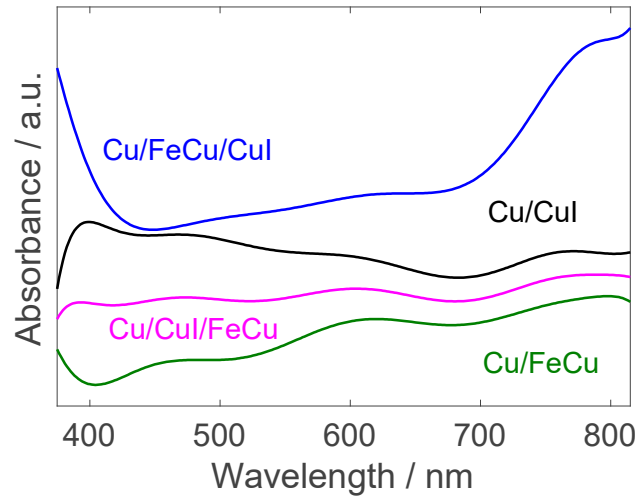

(a)

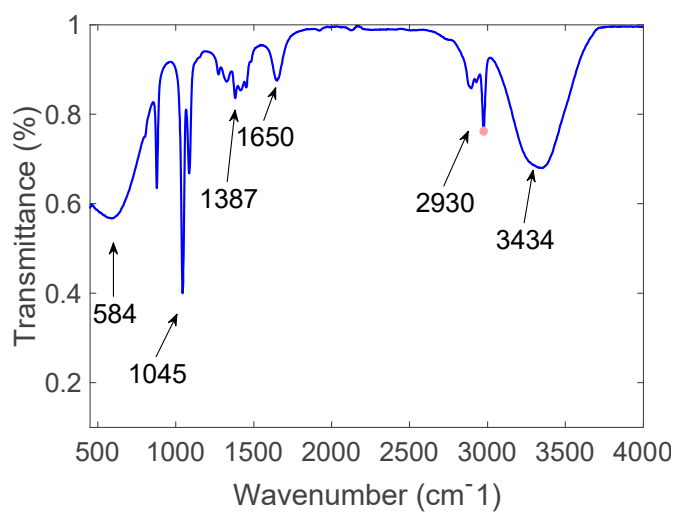

(b)

Figure 7. (a) Spectral absorptivity of produced electrodes and (b) FTIR spectra of the natural Calotropis dye.

The FTIR spectra shown in Figure $7 \mathrm{~b}$ fall within the wave band of $4000 \sim 500 \mathrm{~cm}^{-1}$. The figure identifies the functional groups present in the examined dye samples. The obtained spectrum is in agreement with that found in the literature for chlorophyll extracts. Natural dyes are known to be effective sensitizers for the $\mathrm{TiO}_{2}$ mesoporous structure and Chlorophyll has a bandgap of around $1.88 \mathrm{eV}$, which is excellent to enhance the VIS-NIR absorptivity of the cell [41].

\subsection{Solar-Cell Testing Results}

The intended application for the produced tandem material is its incorporation into solar cells sensitized by an organic dye extracted from a natural non-food plant that is abundant in the United Arab Emirates (the Calotropis gigantea). Some of the measured electrical characteristics of each electrode combination are shown in Table 1.

Table 1. Electronic and energy quantities for the produced electrodes.

\begin{tabular}{ccccc}
\hline Material & $\begin{array}{c}\text { Electron Affinity } \\
\text { (EA)/e.V }\end{array}$ & $\begin{array}{c}\text { Work Function } \\
\text { (WF)/e.V }\end{array}$ & $\begin{array}{c}\text { Ionization Energy } \\
\text { (IE)/e.V }\end{array}$ & $\begin{array}{c}\text { Energy } \\
\text { Bandgap/e.V }\end{array}$ \\
\hline $\mathrm{Cu}$ & $1.235[1]$ & $4.53-5.10[3]$ & $7.7264[5]$ & - \\
$\mathrm{CuI}$ & $2.1 \mathrm{eV}[2]$ & $4.9-5.0[4]$ & & $2.79 \exp [42]$ \\
$\mathrm{FeCu}$ & $\mathrm{NA}$ & $\mathrm{NA}$ & $\mathrm{NA}$ & $1.92 \exp [34]$ \\
\hline
\end{tabular}


Considering the high cost of transparent conducting oxides (TCOs), it is very attractive to develop low-cost $\mathrm{Cu}$ electrodes for DSSC. However, the stability of $\mathrm{Cu}$ is a serious concern as it is well known to diffuse in silicon in first-generation solar cells, creating active recombination centers [43]. Furthermore, the high work function (WF) of $\mathrm{Cu}(5.10 \mathrm{eV}$, see Figure $8 \mathrm{a})$ compared to the conduction band edge of $\mathrm{TiO}_{2}$ suggests the insertion of interface materials for efficient electron extraction. In these regards, we investigated DSSC with different $\mathrm{Cu}$-based negative electrode structures, with the cell J-V characteristics shown in Figure 8b, and the extracted cell parameters are presented in Table 2.

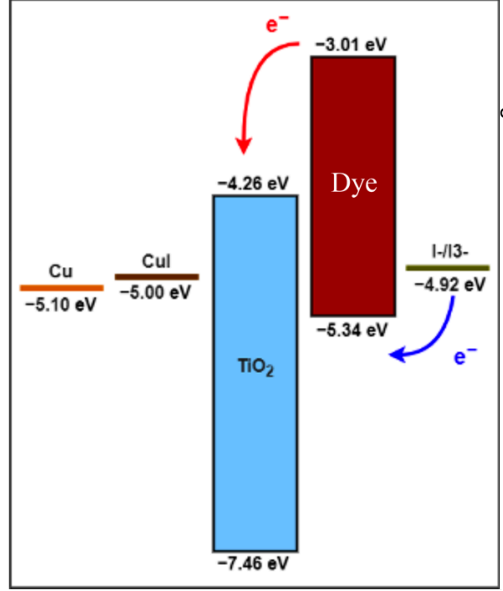

(a)

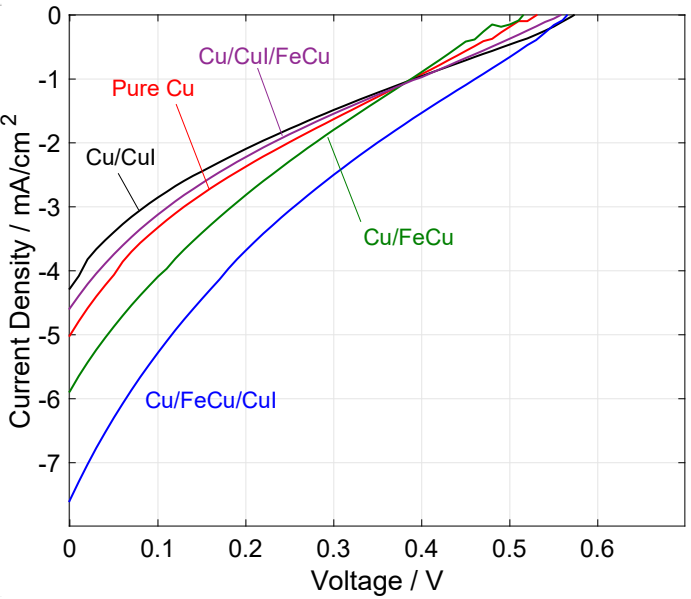

(b)

Figure 8. (a) Band diagram of various DSSC components and (b) J-V characteristic curves for all electrode combinations.

Table 2. Performance characteristics of DSSC constructed using all negative electrode structures.

\begin{tabular}{ccccc}
\hline Negative Electrode Structure & $J_{S C}\left(\mathbf{m A c m}^{-\mathbf{2}}\right)$ & $V_{\boldsymbol{O C}}(\mathrm{V})$ & FF (\%) & PCE (\%) \\
\hline Pure $\mathrm{Cu}$ & 5.00 & 0.530 & 0.187 & 0.497 \\
$\mathrm{Cu} / \mathrm{CuI}$ & 4.27 & 0.570 & 0.184 & 0.448 \\
$\mathrm{Cu} / \mathrm{FeCu}$ & 5.88 & 0.520 & 0.187 & 0.572 \\
$\mathrm{Cu} / \mathrm{CuI} / \mathrm{FeCu}$ & 4.58 & 0.560 & 0.182 & 0.467 \\
$\mathrm{Cu} / \mathrm{FeCu} / \mathrm{CuI}$ & 7.59 & 0.570 & 0.177 & 0.763 \\
Calotropis/Pt (reported) [31] & 0.518 & 0.533 & 0.71 & 0.196 \\
\hline
\end{tabular}

As a reference, DSSC using pure $\mathrm{Cu}$ negative electrode showed a moderate performance, with a 0.497\% power conversion efficiency (PCE). Notably, its low fill factor (FF) and short-circuit current density (JSC) (18\% and $5.00 \mathrm{~mA} / \mathrm{cm}^{-2}$, respectively) are strong indications of the considerable extraction barrier between $\mathrm{Cu}$ and $\mathrm{TiO}_{2}$, as shown in the energy diagram (Figure 8a).

With a slightly lower WF of $5.00 \mathrm{eV}$ compared to that of $\mathrm{Cu}$, we expected $\mathrm{CuI}$ to mitigate the electron extraction losses by providing a more gradual energy step. Indeed, DSSC with all tested variations of $\mathrm{CuI}(\mathrm{Cu} / \mathrm{CuI}, \mathrm{Cu} / \mathrm{CuI} / \mathrm{FeCu}$ and $\mathrm{Cu} / \mathrm{FeCu} / \mathrm{CuI})$ unanimously exhibited higher open-circuit voltages $\left(\mathrm{V}_{\mathrm{OC}}\right)$ compared to the reference $(0.570 \mathrm{~V}, 0.560 \mathrm{~V}, 0.570 \mathrm{~V}$, respectively, vs. $0.530 \mathrm{~V})$. However, $\mathrm{Cu}$-negative electrodes modified with direct $\mathrm{CuI}$ deposition $(\mathrm{Cu} / \mathrm{CuI}$ and $\mathrm{Cu} / \mathrm{CuI} / \mathrm{FeCu})$ resulted in inferior cell PCEs mainly from lower $\mathrm{J}_{\mathrm{SC}}$. We believe that this could be attributed to the inability of $\mathrm{CuI}$ to prevent $\mathrm{Cu}$ diffusion and the creation of active recombination sites; on the contrary, the diffusion may be facilitated by $\mathrm{CuI}$ given its active nature and similar composition to $\mathrm{Cu}$, leading to a deteriorated performance.

In contrast, the results of FeCu-incorporated DSSC seem to suggest a complementary role of the FeCu alloy. While $\mathrm{V}_{\mathrm{OC}}$ was not improved directly in the $\mathrm{Cu} / \mathrm{FeCu}$ cell (suggesting that it is not more energetically favorable compared to CuI), cell PCE was increased considerably compared to the 
reference (from $0.497 \%$ to $0.572 \%$ ). This improvement is likely due to the stabilizing effect of $\mathrm{FeCu}$ deposited on $\mathrm{Cu}$ against $\mathrm{Cu}$ diffusion, which was absent in the structure of $\mathrm{Cu} / \mathrm{CuI} / \mathrm{FeCu}$ where $\mathrm{CuI}$ prevented $\mathrm{FeCu}$ from stabilizing the $\mathrm{Cu}$ electrode (indicated by its similarly low performance compared to $\mathrm{Cu} / \mathrm{CuI}$ ). Finally, the most efficient electrode design was found in the $\mathrm{Cu} / \mathrm{FeCu} / \mathrm{CuI}$ cell, where the full potential of $\mathrm{FeCu}$ and $\mathrm{CuI}(\mathrm{Cu}$ diffusion stabilizing and electron transport, respectively) was fully achieved, giving rise to a high $\mathrm{JSC}_{\mathrm{SC}}$ of $7.59 \mathrm{~mA} / \mathrm{cm}^{-2}, \mathrm{~V}_{\mathrm{OC}}$ of $0.570 \mathrm{~V}$ and PCE of $0.763 \%$. While synthetic Ru-based sensitizers are able to achieve a high PCE in DSSCs, they suffers from major drawbacks, such as a very high cost due to the rarity of the metal, complex synthesis and purification process and low stability [9-11].

In light of these limitations, natural sensitizers provide a promising alternative for realizing cost-effective DSSCs due to the abundance of natural dyes and the usually simple preparation procedures. Nevertheless, the development of DSSCs based on natural sensitizers (such as the Calotropis dye proposed in this work) is still in early stages as the most efficient device only showed PCEs of $0.278 \%-0.50 \%[31,35]$, which are within the range of the performance reported in this work. We would also like to point out that the obtained PCEs reported here are in combination with the use of copper-based counter electrodes which traditionally offer much lower costs at the expense of a lower performance compared to Pt. We believe that the strategy reported here is applicable to more efficient DSSC architectures, which would constitute a future study.

\section{Conclusions}

This work presents the synthesis and characterization of various materials applied to a copper substrate. As a cheap and available material, copper poses some challenges when used for solar cell applications. Here, we showcased two materials deposited on a copper substrate, namely copper iodine and $\mathrm{FeCu}$. The former was chosen due to its compatibility with the iodine/triiodide electrolyte often used in dye-sensitized solar cells and also because it can be intrinsically grown on the copper material. $\mathrm{FeCu}$, on the other hand, is an alloy that has distinct optical and structural properties that are worth investigating. The two materials were added in tandem for the solar cell application, and the synthesis parameters as well as characterization show the facile and rapid implementation, which would positively affect time and cost required for cell manufacture, with amenable properties both optically (e.g., bandgap) and structurally. The produced cells were sensitized with a natural dye extracted from the leaves of a locally abundant plant (Calotropis gigantea), that is, cannot be used as a food item for neither people nor livestock due to the irritating secretions from the stems. The efficiencies of the solar cells show the positive effect of adding $\mathrm{FeCu}$ on top of the copper substrate while adding the $\mathrm{CuI}$ successively over the $\mathrm{FeCu}$. The bandgap match of these two substrates allowed a better spectral interaction with incident radiation during testing, while $\mathrm{CuI}$ had a better compatibility with the electrolyte. The reported efficiency of $0.763 \%$ for the $\mathrm{Cu} / \mathrm{FeCu} / \mathrm{CuI}$ arrangement is higher than the values reported in the literature for similar chlorophyll II-sensitized solar cells $(\sim 0.19 \%)$. This is a promising development, especially since the price of such cells with a copper electrode is low compared with the more expensive platinized materials and would enhance the figure of merit $(\$ / W)$ once further development on the materials and structure is attempted in future work.

Author Contributions: Conceptualization, methodology and resources: A.H.A.; formal analysis, M.F. and K.A., investigation, M.F., K.A. and A.A.H.; data curation, M.F. and K.A., writing-original draft preparation, A.H.A., M.F., and K.A., D.Z. and M.T., writing-review and editing, A.H.A. visualization, A.H.A. supervision, A.H.A., project administration, A.H.A., funding acquisition, A.H.A. All authors have read and agreed to the published version of the manuscript.

Funding: This research was funded by University of Sharjah, Grant/Award Numbers: 1702040681-P and 1802040691-P; Sharjah Research Academy.

Conflicts of Interest: The authors declare no conflict of interest. 


\section{References}

1. Sharma, S.; Jain, K.K.; Sharma, A. Solar Cells: In Research and Applications-A Review. Mater. Sci. Appl. 2015, 06, 1145-1155. [CrossRef]

2. Gros, C.P.; Michelin, C.; Bucher, L.; Desbois, N.; Devillers, C.H.; Coutsolelos, A.G.; Biswas, S.; Sharma, G.D. Synthesis and characterization of zinc carboxy-porphyrin complexes for dye sensitized solar cells. New J. Chem. 2018, 42, 8151-8159. [CrossRef]

3. O'Regan, B.; Grätzel, M. A low-cost, high-efficiency solar cell based on dye-sensitized colloidal TiO2 films. Nature 1991, 353, 737-740. [CrossRef]

4. Sugathan, V.; John, E.; Sudhakar, K. Recent improvements in dye sensitized solar cells: A review. Renew. Sustain. Energy Rev. 2015, 52, 54-64. [CrossRef]

5. Lim, S.M.; Moon, J.; Choi, G.H.; Baek, U.C.; Lim, J.M.; Park, J.T.; Kim, J.H. Surface carbon shell-functionalized $\mathrm{ZrO} 2$ as nanofiller in polymer gel electrolyte-based dye-sensitized solar cells. Nanomaterials 2019, 9, 1418. [CrossRef]

6. Iglesias, D.; Atienzar, P.; Vázquez, E.; Herrero, M.A.; García, H. Carbon nanohorns modified with conjugated terthienyl/terthiophene structures: Additives to enhance the performance of dye-sensitized solar cells. Nanomaterials 2017, 7, 294. [CrossRef]

7. Li, Z.; Yu, L.; Wang, H.; Yang, H.; Ma, H. TiO2 Passivation Layer on ZnO Hollow Microspheres for Quantum Dots Sensitized Solar Cells with Improved Light Harvesting and Electron Collection. Nanomaterials 2020, 10, 631. [CrossRef]

8. Cheng, F.; Ou, Y.; Liu, G.; Zhao, L.; Dong, B.; Wang, S.; Wen, S. Novel quasi-solid-state electrolytes based on electrospun poly(Vinylidene fluoride) fiber membranes for highly effcient and stable dye-sensitized solar cells. Nanomaterials 2019, 9, 783. [CrossRef]

9. Kakiage, K.; Aoyama, Y.; Yano, T.; Oya, K.; Fujisawa, J.I.; Hanaya, M. Highly-efficient dye-sensitized solar cells with collaborative sensitization by silyl-anchor and carboxy-anchor dyes. Chem. Commun. 2015, 51, 15894-15897. [CrossRef]

10. Inamdar, A.I.; Sonavane, A.C.; Sharma, S.K.; Im, H.; Patil, P.S. Nanocrystalline zinc oxide thin films by novel double pulse single step electrodeposition. J. Alloys Compd. 2010, 495, 76-81. [CrossRef]

11. Shaikh, J.S.; Shaikh, N.S.; Mali, S.S.; Patil, J.V.; Pawar, K.K.; Kanjanaboos, P.; Hong, C.K.; Kim, J.H.; Patil, P.S. Nanoarchitectures in dye-sensitized solar cells: Metal oxides, oxide perovskites and carbon-based materials. Nanoscale 2018, 10, 4987-5034. [CrossRef] [PubMed]

12. Ren, Y.; Ma, Z.; Bruce, P.G. Ordered mesoporous metal oxides: Synthesis and applications. Chem. Soc. Rev. 2012, 41, 4909-4927. [CrossRef] [PubMed]

13. Dürr, M.; Rosselli, S.; Yasuda, A.; Nelles, G. Band-gap engineering of metal oxides for dye-sensitized solar cells. J. Phys. Chem. B 2006, 110, 21899-21902. [CrossRef]

14. Alami, A.H.; Rajab, B.; Abed, J.; Faraj, M.; Hawili, A.A.; Alawadhi, H. Investigating various copper oxides-based counter electrodes for dye sensitized solar cell applications. Energy 2019, 174, 526-533. [CrossRef]

15. Sharma, S.K.; Inamdar, A.I.; Im, H.; Kim, B.G.; Patil, P.S. Morphology dependent dye-sensitized solar cell properties of nanocrystalline zinc oxide thin films. J. Alloys Compd. 2011, 509, 2127-2131. [CrossRef]

16. Chen, M.; Shao, L.L. Review on the recent progress of carbon counter electrodes for dye-sensitized solar cells. Chem. Eng. J. 2016, 304, 629-645. [CrossRef]

17. Ahmed, U.; Alizadeh, M.; Rahim, N.A.; Shahabuddin, S.; Ahmed, M.S.; Pandey, A.K. A comprehensive review on counter electrodes for dye sensitized solar cells: A special focus on Pt-TCO free counter electrodes. Sol. Energy 2018, 174, 1097-1125. [CrossRef]

18. Alami, A.H.; Rajab, B.; Aokal, K. Assessment of silver nanowires infused with zinc oxide as a transparent electrode for dye-sensitized solar cell applications. Energy 2017, 139, 1231-1236. [CrossRef]

19. Vijaya, S.; Landi, G.; Wu, J.J.; Anandan, S. MoS2 nanosheets based counter electrodes: An alternative for Pt-free dye-sensitized solar cells. Electrochim. Acta 2019, 294, 134-141. [CrossRef]

20. Huang, J.; Qian, X.; Yang, J.; Niu, Y.; Xu, C.; Hou, L. Construction of Pt-free electrocatalysts based on hierarchical CoS2/N-doped C@Co-WS2 yolk-shell nano-polyhedrons for dye-sensitized solar cells. Electrochim. Acta 2020, 340, 135949. [CrossRef] 
21. Kim, C.K.; Ji, J.M.; Zhou, H.; Lu, C.; Kim, H.K. Tellurium-doped, mesoporous carbon nanomaterials as transparent metal-free counter electrodes for high-performance bifacial dye-sensitized solar cells. Nanomaterials 2020, 10, 29. [CrossRef] [PubMed]

22. Nan, H.; Han, J.; Luo, Q.; Yin, X.; Zhou, Y.; Yao, Z.; Zhao, X.; Li, X.; Lin, H. Economically synthesized NiCo 2 $\mathrm{S} 4$ /reduced graphene oxide composite as efficient counter electrode in dye-sensitized solar cell. Appl. Surf. Sci. 2018, 437, 227-232. [CrossRef]

23. Alami, A.H.; Allagui, A.; Alawadhi, H. Microstructural and optical studies of CuO thin films prepared by chemical ageing of copper substrate in alkaline ammonia solution. J. Alloys Compd. 2014, 617, 542-546. [CrossRef]

24. Alami, A.H.; Allagui, A.; Alawadhi, H. Synthesis and optical properties of electrodeposited crystalline Cu2O in the Vis-NIR range for solar selective absorbers. Renew. Energy 2015, 82, 21-25. [CrossRef]

25. Zhuang, S.; Lu, M.; Zhou, N.; Zhou, L.; Lin, D.; Peng, Z.; Wu, Q. Cu modified ZnO nanoflowers as photoanode material for highly efficient dye sensitized solar cells. Electrochim. Acta 2019, 294, 28-37. [CrossRef]

26. Mohammadnezhad, M.; Liu, M.; Selopal, G.S.; Navarro-Pardo, F.; Wang, Z.M.; Stansfield, B.; Zhao, H.; Lai, C.Y.; Radu, D.R.; Rosei, F. Synthesis of highly efficient Cu2ZnSnSxSe4-x (CZTSSe) nanosheet electrocatalyst for dye-sensitized solar cells. Electrochim. Acta 2020, 340, 135954. [CrossRef]

27. Uthayaraj, S.; Karunarathne, D.G.B.C.; Kumara, G.R.A.; Murugathas, T.; Rasalingam, S.; Rajapakse, R.M.G.; Ravirajan, P.; Velauthapillai, D. Powder pressed cuprous iodide (CuI) as a hole transporting material for perovskite solar cells. Materials 2019, 12, 2037. [CrossRef]

28. Yamada, N.; Ino, R.; Ninomiya, Y. Truly Transparent p-Type $\gamma$-CuI Thin Films with High Hole Mobility. Chem. Mater. 2016, 28, 4971-4981. [CrossRef]

29. Sepalage, G.A.; Meyer, S.; Pascoe, A.; Scully, A.D.; Huang, F.; Bach, U.; Cheng, Y.-B.; Spiccia, L. Copper(I) Iodide as Hole-Conductor in Planar Perovskite Solar Cells: Probing the Origin of $J-V$ Hysteresis. Adv. Funct. Mater. 2015, 25, 5650-5661. [CrossRef]

30. Semalti, P.; Sharma, S.N. Dye Sensitized Solar Cells (DSSCs) Electrolytes and Natural Photo-Sensitizers: A Review. J. Nanosci. Nanotechnol. 2019, 20, 3647-3658. [CrossRef]

31. Bonomo, M.; Di Girolamo, D.; Piccinni, M.; Dowling, D.P.; Dini, D. Electrochemically deposited NiO films as a blocking layer in p-type dye-sensitized solar cells with an impressive $45 \%$ fill factor. Nanomaterials 2020, 10, 167. [CrossRef] [PubMed]

32. Alami, A.H.; Hawili, A.A.; Chaker, N. Experiments on surface hardening of aluminum components by high-energy centrifugal milling. Int. J. Adv. Manuf. Technol. 2018, 95, 3855-3862. [CrossRef]

33. Alami, A.H.; Zhang, D.; Aokal, C.; Abed, J.; Abdoun, I.A.; Alawadhi, H. Influence of Magnetic Field on the Mesoporous Structure of Fe-Cu Compounds in Dye-Sensitized Photovoltaic Cells. Metall. Mater. Trans. E 2016, 3, 37-45. [CrossRef]

34. Alami, A.H.; Abed, J.; Almheiri, M.; Alketbi, A.; Aokal, C. Fe-Cu metastable material as a mesoporous layer for dye-sensitized solar cells. Energy Sci. Eng. 2016, 4, 166-179. [CrossRef]

35. Hosseinnezhad, M.; Gharanjig, K.; Yazdi, M.K.; Zarrintaj, P.; Moradian, S.; Saeb, M.R.; Stadler, F.J. Dye-sensitized solar cells based on natural photosensitizers: A green view from Iran. J. Alloys Compd. 2020, 828, 154329. [CrossRef]

36. Richhariya, G.; Kumar, A.; Tekasakul, P.; Gupta, B. Natural dyes for dye sensitized solar cell: A review. Renew. Sustain. Energy Rev. 2017, 69, 705-718. [CrossRef]

37. Chang, H.; Lo, Y.J. Pomegranate leaves and mulberry fruit as natural sensitizers for dye-sensitized solar cells. Sol. Energy 2010, 84, 1833-1837. [CrossRef]

38. Yang, C.; Kneib, M.; Lorenz, M.; Grundmann, M. Room-Temperature synthesized copper iodide thin filmas degenerate p-Type transparent conductor with a boosted figure of merit. Proc. Natl. Acad. Sci. USA 2016, 113, 12929-12933. [CrossRef]

39. Potts, J.E.; Hanson, R.C.; Walker, C.T.; Schwab, C. Raman scattering from CuBr and CuI. Solid State Commun. 1973, 13, 389-392. [CrossRef]

40. Shan, M.; Jiang, H.; Guan, Y.; Sun, D.; Wang, Y.; Hua, J.; Wang, J. Enhanced hole injection in organic light-emitting diodes utilizing a copper iodide-doped hole injection layer. RSC Adv. 2017, 7, 13584-13589. [CrossRef] 
41. Syafinar, R.; Gomesh, N.; Irwanto, M.; Fareq, M.; Irwan, Y.M. Chlorophyll Pigments as Nature Based Dye for Dye-Sensitized Solar Cell (DSSC). In Proceedings of the Energy Procedia; Elsevier Ltd, New York, NY, USA, 2015; Volume 79, pp. 896-902. [CrossRef]

42. Alami, A.; Faraj, M.; Aokal, K.; Majeed, A.; Zhang, D.; Tawalbeh, M.; Salameh, T.; Al-Othman, A. Synthesis and Characterization of Polycrystalline Copper Iodide (CuI) Thin Films. In Proceedings of the Advances in Science and Engineering Technology (ASET), Sharjah, UAE, 9 April 2020.

43. Lennon, A.; Colwell, J.; Rodbell, K.P. Challenges facing copper-plated metallisation for silicon photovoltaics: Insights from integrated circuit technology development. Prog. Photovoltaics Res. Appl. 2019, 27, 67-97. [CrossRef]

(C) 2020 by the authors. Licensee MDPI, Basel, Switzerland. This article is an open access article distributed under the terms and conditions of the Creative Commons Attribution (CC BY) license (http://creativecommons.org/licenses/by/4.0/). 